\title{
Pengaruh Good Corporate Governance dan Holding Company terhadap Kinerja Keuangan
}

(Studi pada Perusahaan Konstruksi Periode Tahun 2014 - 2017)

\author{
LISTIYOWATI \\ WENNY ANAADNANTI \\ IIN INDARTI \\ Jurusan Akuntansi, Sekolah Tinggi Ilmu Ekonomi Widya Manggala \\ Jalan Sriwijaya No. 32 \& 36 Semarang 50242 \\ Email: tiyox_banget@yahoo.com
}

Diterima 23 Februari 2019; disetujui 4 Maret 2019;

\begin{abstract}
This study aimed to examine the effect of institutional ownership, independent commissioner and holding company on return on assets. The test results on a sample of 40 construction companies from 2014 to 2017 using regression analysis. Institutional ownership and independent commissioners had no effect on return on assets, while holding company had a significant effect on returns on assets in construction companies in IDX. When simultaneous testing of the three independent variables above had a significant effect on the dependent variable. The coefficient of determination is $16.2 \%$ which shows that the researchd capital framework is not good enough to explain the dependent variable.
\end{abstract}

Keywords: Institutional Ownership, Independent Commissioner, Holding Company, Return On Assets

\section{PENDAHULUAN}

Latar Belakang. Sektor konstruksi menempati posisi ketiga sebagai pendorong pertumbuhan ekonomi di Indonesia sepanjang tahun 2016, dengan kontribusi 0,52\% setelah sektor industri pengolahan dan sektor perdagangan. Berdasarkan data Badan Pusat Statistik, ekonomi Indonesia pada tahun 2016 tumbuh sebesar 5,02\%,lebih tinggi dibandingkan tahun 2015 yang mencapai 4,88\%. Kontribusi sektor konstruksi bagi pembentukan produk domestik bruto (PDB) cukup signifikan, yakni sebesar 10,38\%. Angka ini menjadikannya di urutan ke-4 setelah sektor industri,pertanian dan perdagangan. Namun demikian data perusahaan konstruksi yang terdaftar di BEI tahun 2014-2017 menunjukkan rata-rata profit -0.285 , dan terdapat empat perusahaan konstruksi yang melaporkan kerugian tiap tahunnya. Salah satu penyebab utamanya kemungkinan adalah dari sisi tata kelola perusahaan. Tata kelola yang harus dilaksanakan dalam perusahaan salah satunya adalah tata kelola keuangan. Tata kelola keuangan ini sangat penting untuk dilakukan untuk menaikkan performa perusahaan. Perusahaan yang menjunjung prinsip GCG diharapkan dapat secara sehat tumbuh dengan tetap menjaga keseimbangan dan tidak merugikan kepenting an pihak lain. Good Corporate Governance merupakan tata kelola perusahaan yang menjelaskan hubungan antara berbagai partisipan dalam perusahaan yang menentukan arah dan kinerja perusahaan. GCG dilakukan sebagai upaya untuk memastikan bahwa manajer perusahaan selalu mengambil tindakan yang tepat dan tidak mementingkan diri sendiri. (Hery, 2015). 
Mekanisme corporate governance yang diteliti dalam penelitian ini adalah kepemilikan institusional dan proporsi komisaris independen. Kepemilikan institusional merupakan kepemilikan saham perusahaan oleh institusi seperti perusahaan asuransi, bank, perusahaan investasi, reksa dana, perusahaan investasi, reksa dana, dan institusi lainnya. Kepemilikan institusional yang tinggi menimbulkan pengawasan yang lebih besar oleh pihak investor intitusional sehingga dapat menghalangi perilaku opportunistic manajer. (Hery, 2014). Kepemilikan institusional bertindak sebagai pengawas dalamkinerja perusahaan. Semakin baik tingkat pengawasan yang dilakukan maka akan mengakibatkan sistem bekerja dengan baik. Meminimalkan tingkat pelanggaran dan kinerja manajemen juga akan meningkat. Yang secara langsung akan berdampak pada tingkat pendapatan perusahaan. Hal ini diperkuat oleh penelitian Ali Muktiyanto (2011) yang menyatakan bahwa kepemilikan institusional berpengaruh positif signifikan terhadap kinerja perusahaan. Tetapi hal ini berbeda dengan penelitian Astri Aprianingsih (2016) bahwa kepemilikan institusional berpengaruh negatif terhadap kinerja perusahaan.

Selain kepemilikan institusional tindakan manajemen perusahaan juga dapat diawasi dengan adanya komisaris independen. Komisaris independen diharapkan mampu menempatkan keadilan sebagai prinsip utama dalam memperhatikan kepentingan pihak-pihak yang mungkin sering terabaikan, seperti pemegang saham minoritas dan para stakeholders lainnya (Herry, 2015). Komisaris independen merupakan anggota komisaris yang tidak mempunyai hubungan dengan anggota komisaris lainnya, anggota dewan direksi, dan pemegang saham pengendali. Komisaris independen berjumlah proporsional dengan jumlah saham dimiliki oleh non pemegang saham pengendali. Ketentuannya adalah jumlah komisaris independen sekurang-kurangnya harus $30 \%$ dari seluruh anggota komisaris. Komisaris independen bisa merangkap sebagai ketua komite audit. (Mohammad Samsul, 2006). Semakin kecil jumlah komisaris independen akan berdampak terhadap kinerja perusahaan yang semakin meningkat, karena hal ini tidak menimbulkan tumpang tindih informasi dan kebijakan yang nantinya akan disampaikan kepada direksi di perusahaan. Hal ini di perkuat oleh penelitian Ali Muktiyanto (2011) yang menyatakan bahwa komisaris independen berpengaruh negatif signifikan terhadap kinerja perusahaan. Hal ini berbeda dengan penelitian yang dilakukan oleh Astri Aprianingsih (2016) bahwa dewan komisaris berpengaruh negatif tidak signifikan terhadap kinerja perusahaan.

Faktor lain yang mampu mempengaruhi kinerja keuangan adalah perusahaan holding. Perusahaan Holding adalah sebuah perusahaan yang memiliki saham di perusahaan lain dengan jumlah yang cukup sehingga memungkinkan untuk mengontrol perusahaan lain secara tidak langsung. Kegiatan operasi perusahaan dalam holding company terpisah, maka kewajiban satu unit anak perusahaan terpisah dengan anak perusahaan lainnya. Dengan demikian kegagalan satu unit usaha dapat ditutup oleh satu keberhasilan usaha lain. (Sartono, 2010). Penelitian yang menguatkan konsep ini adalah Norman N.Bowsher (1978) yang menyebutkan bahwa holding company mempunyai pengaruh terhadap kinerja perusahaan. Sedangkan menurut penelitian yang dilakukan oleh Lee \& Geon Ho (2017) bahwa holding company tidak mampu mempengaruhi Kinerja perusahaan.

Tujuan Penelitian. Berdasarkan latar belakang diatas maka tujuan penelitian ini adalah untuk menguji pengaruh Good Corporate Governance dan Holding Company terhadap Kinerja Keuangan pada perusahaan konstruksi yang terdaftar di Bursa Efek Indonesia Tahun 2014-2017.

\section{TINJAUAN TEORETIS}

Teori Agency. Agency Theory pertama kali diperkenalkan oleh Jensen dan Meckling pada tahun 1976. Teori ini mendefinisikan hubungan keagenan sebagai kontrak antara prinsipal (pemilik sumber daya) dan agen (manajer). Suryarama (2009) menjelaskan bahwa perusahaan merupakan kumpulan kontrak (nexus of contract) antara pemilik sumber daya ekonomis (principal) dan manajer (agent) yang mengurus penggunaan dan pengendalian sumber daya tersebut. Dalam upaya mengatasi atau mengurangi masalah keagenan ini menimbulkan biaya keagenan (agency cost) yang akan ditanggung baik oleh principal maupun agent. 
Biaya keagenan ini terdiri dari monitoring cost, bonding cost dan residual cost. Monitoring cost adalah biaya yang timbul dan ditanggung oleh principal untuk memonitor perilaku agent, yaitu untuk mengukur, mengamati, dan mengontrol perilaku agent. Bonding cost merupakan biaya yang ditanggung oleh agent untuk menetapkan dan mematuhi mekanisme yang menjamin bahwa agent akan bertindak untuk kepentingan principal. Selanjutnya residual loss merupakan pengorbanan yang berupa berkurangnya kemakmuran principal sebagai akibat dari perbedaan keputusan agent dan keputusan principal.

Permasalahan keagenan bisa di pecahkan melalui mekanisme good corporate governance yaitu kepemilikan institusional dan komisaris independen. Semakin tinggi tingkat tata kelola perusahaan maka perbedaan kepentingan antara agen dan principal bisa diatasi. Tingginya tingkat pengawasan yang dilakukan oleh pihak investor maka akan berdampak terhadap kinerja manajemen dalam mengelola perusahaan. Selain dengan good corporate governance, holding company juga diharapkan mampu mengatasi permasalahan keagenan dalam perusahaan. Pengawasan yang dilakukan perusahaan induk ke perusahaan anak akan berdampak terhadap kinerja manajamen anak dan hal ini akan memberikan dampak terhadap perusahaan induk secara langsung. Diantaranya adalah menutup kerugian perusahaan induk. Sehingga hal ini akan berdampak terhadap kinerja perusahaan yang semakin baik dimata pemilik dana.

Kinerja Keuangan. Kinerja keuangan digunakan untuk mengukur seberapa besar kemampuan perusahaan dalam mengelola keuangan untuk memberikan dampak positif terhadap perusahaan. Untuk mengetahui seberapa besar tingkat keuangan yang baik yang dimiliki oleh perusahaan melalui analisis laporan keuangan. Dalam penelitian ini analisis keuangan yang digunakan adalah rasio keuangan profitabilitas. Rasio ini digunakan untuk menilai kemampuan perusahaan dalam mencari keuntungan, selain itu digunakan untuk memberikan ukuran tingkat efektivitas manajemen suatu perusahaan. (Kasmir, 2015). Proxy yang digunakan dalam penelitian ini adalah Return On Assets (ROA). ROA ini digunakan untuk menunjukkan hasil (revenue) atas jumlah aktiva yang digunakan dalam perusahaan. Disamping itu hasil pengembalian investasi menunjukkan produktivitas dari seluruh dana perusahaan, baik modal pinjaman maupun modal sendiri. Mengacu pada rumusan masalah dalam penelitian ini dan dukungan konsep Subagyo dkk (2018) bahwa mekanisme good corporate governance mampu mempengaruhi kinerja manajamen diantaranya adalah kepemilikan institusional dan komisaris independen. Serta konsep Sartono (2010) yang menyatakan bahwa company holding sebagai pengendali kepemilikan dalam menghindarikegagalan usaha.

Kepemilikan Institusional. Salah satu faktor yang mempengaruhi kinerja manajemen adalah kepemilikan institusional. Kepemilikan institusional di suatu perusahaan akan mendorong peningkatan pengawasan agar lebih optimal terhadap kinerja manajemen, karena kepemilikan saham mewakili suatu sumber kekuasaan yang dapat digunakan untuk mendukung atau sebaliknya terhadap kinerja manajemen. (Subagyo dkk, 2018). Kepemilikan institusional adalah kepemilikan saham perusahaan oleh institusi keuangan. Tingkat kepemilikan institusional yang tinggi akan menimbulkan pengawasan yang lebih besar oleh pihak investor institusional sehingga dapat menghalangi perilaku opportunistic manajer. Perusahaan dengan kepemilikan institusional mayoritas mengindikasikan kemampuannya untuk memonitor manajemen. (Hery, 2014).

Kepemilikan institusional diharapkan mampu mengatasi permasalahan keagenan antara pemilik dan manajemen sebagai pengelola perusahaan. Dengan adanya kepemilikan saham oleh pemerintah, institusi keuangan, institusi berbadan hukum, institusi luar negeri, dana perwalian dan institusi lainnya pada akhir tahun diharapkan akan menjadi tolak ukur dalam menghasilkan kinerja manajemen yang mampu dipertanggungjawabkan kepada investor.

Komisaris Independen. Kepentingan investor harus dijaga diantaranya dengan mengangkat komisaris independen. Komisaris independen adalah anggota komisaris yang tidak mempunyai hubungan dengan anggota komisaris lainnya, anggota dewan komisaris yang tidak mempunyai hubungan dengan anggota komisaris lainnya, anggota dewan direksi, dan pemegang saham pengendali. (Mohammad Samsul, 2006). Pelak- 
sanaan prinsip good corporate governance dalam dunia usaha sekarang ini memerlukan komisaris independen yang duduk dalam jajaran pengurus perseroan. Komisaris independen tidak hanya sebagai simbol belaka karena pada praktiknya tidak jarang komisaris independen hanya diperlukan sebagai shock therapy bagi orang-orang yang bermaksud tidak baik terhadap peerseroan. Didalam suatu perseroan diwajibkan mempunyai sekurang-kurangnya satu orang komisaris independen, yang berasal dari luar perusahaan serta tidak mempunyai hubungan bisnis dengan perusahaan atau afiliasinya. (Adrian Sutedi, 2015).

Holding Company. Holding company diharapkan dapat menyelesaikan konflik kepentingan antara agen (manajemen) dan principal (pemilik) dalam perusahaan. Semakin tinggi tingkat kepemilikan saham perusahaan maka hal ini akan membantu perusahaan untuk selalu going concern. Karena hal ini bisa menutup kerugian apabila perusahaan holding mengalami kerugian. Ketika perusahaan holding mampu melakukan pengawasan secara baik terhadap perusahaan anak maka akan berdampak terhadap kinerja perusahaan anak yang berdampak langsung juga terhadap perusahaan holding. Ketika perusahaan holding mampu menutup setiap kerugian dan menambah tingkat keuntungan yang diakibatkan oleh perusahaan anak maka secara langsung akan meningkatkan kinerja perusahaan dan tingkat kepercayaan pemilik akan semakin tinggi.

Perusahaan holding mempunyai kepentingan pengawasan dalam perusahaan lainnya. Atau perusahaan yang memiliki/mengawasi atau mempunyai kekuasaan untuk memberikan suara sebanyak $10 \%$ dari suatu perusahaan publik. Perusahaan holding bertujuan untuk memiliki saham dalam satu atau lebih perusahaan lain dan/atau mengatur satu atau lebih perusahaan lain tersebut. Biasanya (walaupun tidak selamanya) suatu perusahaan holding memiliki banyak perusahaan yang bergerak dalam bidangbidang yang sangat berbeda-beda. (Munir Fuady, 2009).

Hipotesis. Berdasarkan tinjauan teoretis dan penelitian terdahulu, maka hipotesis yang diajukan pada penelitian ini antara lain:

$\mathrm{H}_{1}$ : Kepemilikan institusional berpengaruh positif terhadap ROA pada perusahaan konstruksi di BEI tahun 2014-2017.

$\mathrm{H}_{2}$ : Komisaris Independen berpengaruh negatif terhadap ROA pada perusahaan konstruksi di BEI tahun 2014-2017.

$\mathrm{H}_{3}$ : Holding Company berpengaruh positif terhadap ROA pada perusahaan konstruksi di BEI tahun 2014-2017.

\section{METODE PENELITIAN}

Populasi dan Sampel. Populasi dalam penelitian ini adalah perusahaan konstruksi yang terdaftar di BEI tahun 2014-2017. Jenis data yang digunakan dalam penelitian ini adalah data sekunder yang bersumber dari publikasi Laporan Keuangan di BEI Tahun 2014-2017. Populasi dalam penelitian ini adalah 64 perusahaan untuk keseluruhan tahun observasi. Teknik pengambilan sampling dalam peneltian ini adalah purposive sampling dengan kriteria pada Tabel 1.

Berdasarkan tabel kriteria pada tabel 1 maka didapatkan sampel berjumlah 40 perusahaan pada tahun observasi.

Definisi Operasional. Variabel dependen adalah kinerja keuangan dengan proxy yang digunakan adalah Return On Assets (ROA). ROA adalah rasio yang menunjukkan hasil (return) atas jumlah aktiva yang digunakan dalam perusahaan.

$\mathrm{ROA}=\frac{\text { Earning After Interest and Tax }}{\text { Total Assets }}$

Variabel independen dalam penelitian ini adalah :

1. Kepemilikan Institusional (KI); adalah

Tabel 1

Teknik Pengambilan Sampling

\begin{tabular}{llllll}
\hline No. & \multicolumn{3}{c}{ Keterangan } & \multicolumn{3}{c}{ Jumlah Perusahaan } \\
& & 2014 & 2015 & 2016 & 2017 \\
\hline 1 & Perusahaan Konstruksi yang terdaftar di BEI tahun 2014-2017. & 16 & 16 & 16 & 16 \\
2 & $\begin{array}{l}\text { Perusahaan Konstruksi yang melaporkan LK berturut-turut } \\
\text { antara tahun 2014 sd tahun 2017 }\end{array}$ & 10 & 10 & 10 & 10 \\
\hline
\end{tabular}


kepemilikan saham perusahaan oleh institusi keuangan.

$\mathrm{KI}=\frac{\text { Jumlah Lembar Saham yang dimiliki investor instituisional }}{\text { Jumlah Lembar Saham Yang Beredar }}$

2. Komisaris Independen; adalah anggota komisaris yang tidak mempunyai hubungan dengan anggota komisaris lainnya, anggota dewan komisaris yang tidak mempunyai hubungan dengan anggota komisaris lainnya, anggota dewan direksi, dan pemegang saham pengendali. (Mohammad Samsul, 2006).

DKI $=\frac{\text { Proporsi Komisaris Independen }}{\text { Total Jumlah Komisaris pada Perusahaan }}$

\section{Holding Company}

Perusahaan holding bertujuan untuk memiliki saham dalam satu atau lebih perusahaan lain dan/ atau mengatur satu atau lebih perusahaan lain tersebut.

Variabel ini akan diukur dari jumlah anak perusahaan yang beroperasi yang dimiliki oleh perusahaan secara langsung dan tidak langsung.

Metode Analisis Data. Data yang terkumpul dalam penelitian ini akan diuji menggunakan model regresi berganda dengan model sebagai berikut :

$\boldsymbol{w}=\mathrm{a}+\mathrm{b}_{1} \mathrm{X}_{1}+\mathrm{b}_{2} \mathrm{X}_{2}+\mathrm{b}_{3} \mathrm{X}_{3}$

Keterangan :

$\begin{array}{ll}w & : \text { Return On Asets (ROA) } \\ a & : \text { konstanta } \\ b 1, b 2, b 3 & : \text { koefisien } \\ X 1 & : \text { Kepemilikan Institusional } \\ X 2 & : \text { Komisaris Independen } \\ X 3 & : \text { Holding Company }\end{array}$

\section{HASIL DAN PEMBAHASAN}

Hasil Analisis Regresi Berganda. Berdasarkan hasil olah data didapatkan hasil seperti tampak dalam tabel 2, kemudian disusun rumus regresi sebagai berikut:

$\mathrm{ROA}=-0.140-0.182 \mathrm{KI}+0.301 \mathrm{DKI}+0.162 \mathrm{HC}$ Persamaan diatas menunjukkan :

a. -0.140 merupakan nilai konstanta dapat diartikan apabila variabel bebas yaitu kepemilikan institusional, komisaris independen dan holding company konstan maka nilai ROA sebesar -0.140 .

b. Koefisien regresi $b_{1}$ yaitu kepemilikan institusional $\left(\mathrm{X}_{1}\right)$ sebesar - 0.182 mempunyai arti jika variabel kepemilikan intitusional meningkat 1 satuan dan variabel komisaris independen $\left(\mathrm{X}_{2}\right)$ dan holding company $\left(\mathrm{X}_{3}\right)$ tetap maka nilai variabel ROA (Y) akan turun sebesar 0.182 .

c. Koefisien regresi $b_{2}$ yaitu komisaris indpeenden $\left(\mathrm{X}_{2}\right)$ sebesar 0.301 mempunyai arti jika variabel komisaris independen meningkat 1 satuan dan variabel kepemilikan institusional $\left(\mathrm{X}_{1}\right)$ dan holding company $\left(\mathrm{X}_{3}\right)$ tetap maka nilai variabel ROA (Y) akan naik sebesar 0.301.

d. Koefisien regresi $b_{3}$ yaitu Holding company $\left(\mathrm{X}_{3}\right)$ sebesar 0.162 mempunyai arti jika variabel holding company meningkat 1 satuan dan variabel kepemilikan institusional (X1) dan komisaris independen $\left(\mathrm{X}_{2}\right)$ tetap maka nilai variabel ROA (Y) akan naik sebesar 0.162.

Uji Hipotesis. Hasil uji hipotesis dengan menggunakan analisis regresi linier berganda menunjukkan bahwa:

a. Variabel kepemilikan institusional memiliki thitung sebesar -0,885 < t-tabel 2,081, dengan taraf signifikansinya $0,382>0,05$ maka disimpulkan variabel kepemilikan institusional tidak berpengaruh terhadap ROA.

b. Variabel komisaris independen memiliki t-hitung sebesar $1,157<\mathrm{t}$-tabel 2,081, dengan taraf

Tabel 2

Hasil Analisis Regresi Linier Berganda

Coefficients $^{a}$

\begin{tabular}{|c|c|c|c|c|c|c|}
\hline & \multirow[t]{2}{*}{ Model } & \multicolumn{2}{|c|}{ Unstandardized Coefficients } & \multirow{2}{*}{$\begin{array}{c}\text { Standardized Coefficients } \\
\text { Beta } \\
\end{array}$} & \multirow[t]{2}{*}{$t$} & \multirow[t]{2}{*}{ Sig. } \\
\hline & & B & Std. Error & & & \\
\hline \multirow[t]{4}{*}{1} & (Constant) & -.140 & .185 & & -.757 & .454 \\
\hline & $\mathrm{KI}$ & -.182 & .205 & -.136 & -.885 & .382 \\
\hline & DKI & .301 & .260 & .177 & 1.157 & .255 \\
\hline & LOGHC & .162 & .057 & .440 & 2.850 & .007 \\
\hline
\end{tabular}

a. Dependent Variable: ROA

Sumber : Hasil Olah SPSS 
signifikansinya 0,255>0,05 maka disimpulkan variabel komisaris independen tidak berpengaruh terhadap ROA

c. Variabel holding company sebesar mempunyai pengaruh positif signifikan terhadap ROA karena nilai t-hitung diatas nilai t tabel yaitu $2.850>$ 2.081 dan signifikansinya dibawah $5 \%$ yaitu 0.007 .

Uji Koefisien Determinasi. Uji ini digunakan untuk mengukur seberapa jauh kemampuan model dalam menerangkan variasi independen. Nilai koefisien determisasi antara 0 dan 1 . Berdasarkan tabel 3 nilai koefisien sebesar $16,2 \%$ dan selebihnya sebesar $82.8 \%$ di terangkan dengan variabel lain diluar variabel yang kita teliti. Hal ini menunjukkan bahwa model tidak cukup baik dimana variasi independen menerangkan.

\section{SIMPULAN}

Kesimpulan. Secara umum hasil penelitian menunjukkan bahwa good corporate governance tidak mempunyai pengaruh terhadap ROA sedangkan holding company berpengaruh positif terhadap ROA.

Saran. Berdasarkan hasil penelitian ini, maka penelitian selanjutnya dapat menerapkan semua mekanisme good corporate governance didalam penelitian dan hendaknya sampel penelitian diperluas atas jenis industri selain perusahaan konstruksi agar hasil penelitian memiliki daya generalisasi yang lebih tinggi serta periode penelitian diperpanjang.

\section{DAFTAR PUSTAKA}

Agus Sartono. 2010. Menejemen Keuangan Teori dan Aplikasi. Edisi 4. BPFE Yogyakarta Ansofino and Yolamalinda and H. Arfilindo and Jolianis. Buku Ajar Ekonometrika. Sumatra Barat : STKIP PGRI
Aprianingsih, Apri. 2016. Effect Good Corporate Governance Implementattion, Ownership Structure, Company Size to Financial Performance. Jurnal Profita Edisi 4 Tahun 2016

Bowsher N, Norman. 1978. Have Multibank Holding Companies Affected Commercial Bank Performance. Federal Reserve Bank Of St. Louis.

Herry. 2014. Controllership Knowledge and Management Approach. Jakarta : PT. Gramedia.

Ho, Geon and Lee. 2017. The Effects of Holding Company Transition on Firm's Market Value and Performance: Empirical Analysis on the U.S. Holding Companies. Department of Economic Seoul National University.

Kasmir, 2015. Analisa Laporan Keuangan. Jakarta : Rajawali Press.

Kementerian Keuangan RI. 2017. 2017 Infrastructure of Budgetting : Kementerian Keuangan RI. Diunduh tanggal 3 September 2001, https://www.kemenkeu.go.id/apbn2017

Muktiyanto, Ali. 2011. Pengaruh Interpendensi Mekanisme Corporate Governance Terhadap Kinerja Perbankan. Jurnal Akuntansi dan Keuangan Indonesia. Volume 8 - No. 2, Desember 2011.

Pearce and Robinson. 2008. Manajemen Strategis Formulasi, Implementasi. Jakarta : Salemba Empat.

Samsul, Mohammad. 2006. Pasar Modal dan Manajemen Portfolio. Surabaya : PT. Gelora Aksara Pratama.

Schwab, Klaus. 2009 : The Global Competitiveness Report. Switzerland : World Economic Forum.

Subagyo and N.A. Maruroh and I. Bastian. 2018. Akuntansi Manajemen Berbasis Design. Yogyakarta : Gadjah Mada University Press Tanjung, Akbar. 1999. Jasa Konstruksi. Jakarta : Undang Undang Nomor 18 Tahun 1999.

Yuliana. 2016. Penerapan Tata Kelola bagi Bank Umum. Jakarta : Peraturan Otritas Jasa Keuangan 